\title{
PENGEMBANGAN BAHAN AJAR GAMIFIKASI BERBASIS CONTEXTUAL TEACHING LEARNING (CTL) PADA MATERI PELUANG
}

\author{
${ }^{1}$ Rini Pangestu, ${ }^{2}$ Netriwati, ${ }^{3}$ Rizki Wahyu Yunian Putra \\ ${ }^{1,2,3}$ Universitas Islam Negeri Raden Intan Lampung, JL. Letkol H. Endro Suratmin Sukarame, Bandar Lampung, \\ (0721) 703260 \\ e-mail: Rinipengestu1@gmail.com
}

\begin{abstract}
Abstrak
Tujuan penelitian ini adalah mengembangkan bahan ajar gamifikasi berbasis Contxtual Teaching Lerning (CTL) layak dan menarik untuk digunakan peserta didik pada jenjang SMP/Mts. Penelitian ini menggunakan model pengembangan ADDIE (Analisys, Desaign, Development, Implementation dan Evaluation). Teknik analisis data pada penelitian ini menggunakan teknik analisis deskriptif kualitatif yang memaparkan hasil pengembangan produk bahan ajar. Data yang diperoleh melalui instrumen ujicoba dianalisis menggunakan statistik deskriptif kualitatif. Hasil validasi ahli materi dari 3 validator menunjukkan bahwa secara keseluruhan produk memperoleh nilai rata-rata sebesar 3,3 dan Hasil validasi ahli media memperoleh nilai rata-rata sebesar 3,6 sedangkan hasil validasi ahli bahasa memperoleh nilai rata-rata sebesar 3,3. Sementara hasil uji coba kelompok kecil dari 15 peserta didik Mts Darul A'mal Metro diperoleh hasil kemenarikan bahan ajar dengan nilai rata-rata 3,3. sedangkan uji coba kelompok besar yang dikalkukan di SMPN 3 Tanjung Raja Lampung Utara memperoleh nilai rata-rata 3,5. Dengan demikian, dapat disimpulkan bahwa pengembangan bahan ajar gamifikasi berbasis contextual teaching learning (CTL) pada kriteria sangat layak dan menarik.
\end{abstract}

Kata Kunci: Gamifikasi, Contextual Teachung Learning (CTL), peluang

\begin{abstract}
The purpose of this research is to develop the teaching material of Gamification based on Contxtual Teaching Lerning (CTL) which is feasible and interesting for learners use in junior high school / Mts. This research uses ADDIE development model (Analisys, Desaign, Development, Implementation and Evaluation). Data analysis techniques in this study using descriptive qualitative analysis techniques that describe the results of product development teaching materials. Data obtained through test instruments were analyzed using qualitative descriptive statistics. Expert material validation result from 3 validator indicate that overall product get average value equal to 3,3 and result of validation of media expert get average value equal to 3,6 while result of validation of linguist get average value equal to 3,3. While the results of small group trial of 15 students Mts Darul A'mal Metro obtained the results of attractiveness of teaching materials with an average value of 3.3. while the large group trial that was admitted in SMPN 3 Tanjung Raja Lampung Utara got an average value of 3.5. Thus, it can be concluded that the development of gamification teaching materials based on contextual teaching learning (CTL) on criteria is very feasible and interesting.
\end{abstract}

Keywords: Gamification, Contextual Teachung Learning (CTL), opportunity

\section{PENDAHULUAN}

Kurikulum sebagai bahan belajar merupakan gambaran kurikulum paling dasar yang menggambarkan suatu kurikulum sebagai kombinasi yang membentuk kerangka isi materi yang diajarkan (Idi Abdullh, 2014, h. 31). Salah satu usaha yang dilakukan pemerintah untuk menghasilkan SDM yang berkualitas dan menyesuaikan perkembangan zaman adalah melakukan pengembangan kurikulum, Kurikulum Tahun 2006 (KTSP) dikembangkan dan diperbaharui menjadi kurikulim 2013. Pelaksanaan Kurikulum 2013 dilaksanakan dengan 
melatihkan keterampilan proses yang dicerminkan dalam kegiatan pembelajaran yang dikenal sebagai pendekatan saintifik.

Saat ini kurikulum 2013 telah diterapkan, namun bahan ajar yang tersedia belum sesuai dengan kurikulum 2013. Diperlukan suatu bahan ajar yang menarik, inovatif, dan kreatif sesuai dengan kurikulum 2013 berupa bahan ajar gamifikasi dengan pendekatan saintifik (Gjosphink Putra Umar And Suci Rohayati, 2015, h. 3). Dalam upaya mencapai tujuan pembelajaran, tentu perlu adanya alat atau media untuk membantu siswa dalam mencapai berbagai kompetensi yang telah ditentukan (Durohma, dkk 2018, h. 2). Senada dengan tuntutan dalam kurikulum 2013 untuk mengutamakan keaktifan peserta didik dalam mencapai kompetensi pembelajaran, pendidik perlu mengembangkan bahan ajar yang berpusat pada peserta didik. Salah satu cara untuk mengembangkan pembelajaran yang efektif dan efesien yaitu dengan mengembangkan bahan ajar gamifikasi.

Berdasarkan hasil wawancara dengan pendidik bidang studi Matematika Bapak Suratno, S.Pd di MTs Darul A'mal Metro mengatakan bahwa pembelajaran matematika pada pokok bahasan peluang, pendidik hanya menggunakan buku yang telah disediakan oleh pemerintah untuk media belajar. Setiap peserta didik memiliki tingkat kesulitan yang berbeda-beda dalam memahami materi ini, karena setiap peserta didik memiliki karakteristik yang berbeda-beda dalam proses belajar. Sejalan dengan permasalahan tersebut, mempengaruhi nilai peserta didik dengan banyaknya peserta didik yang tidak lulus atau tidak memenuhi syarat nilai KKM. Maka dari itu peneliti penggunaan bahan ajar gamifikasi untuk membantu proses belajar mengajar yang lebih efektif, inovatif dan menarik dengan harapan peserta didik dapat lebih memahami materi dan mendapat nilai yang memuaskan khususnya pada materi peluang.

Pembelajaran matematika merupakan sarana berpikir yang jelas dan logis, dapat memecahkan masalah yang ada dikehidupan sehari-hari, serta membutuhkan pemahaman konsep yang mendalam. Belajar matematika bertujuan melatih siswa berpikir sistematis, logis, kritis dan kreatif dalam mengomunikasikan ide atau pemecahan masalah. Akan tetapi, sampai saat ini matematika sebagai ilmu utama dalam pembelajaran masih memberikan "ketakutan" tersendiri pada peserta didik. Akibatnya, dalam proses pembelajaran matematika membutuhkan energi ekstra baik dari pendidik maupun peserta didik.

Oleh karena itu, proses pembelajaran matematika hendaknya dibuat semenarik mungkin agar peserta didik tidak cepat bosan dalam pembelajaran matematika. Salah satu media pembelajaran yang dapat diujikan yaitu menggunakan bahan ajar gamifikasi. Gamifikasi menurut Meyhart Bangkit Sitorus adalah penggunaan elemen-elemen game dan teknik desain 
game dalam konteks non game. elemen game yaitu seperti poin, lencana, tingkatan, narasi dan sebagainya, tetapi seiring perkembangan inti dari gamifikasi saat ini adalah bagaimana untuk membangun motifasi dan ketertarikan peserta didik dalam belajar.

Bahan ajar yang bagus selalu mengikuti perkembangan teknologi, seni dan realitas kehidupan di dalam masyarakat yang semakin mengglobal. Pengembangan bahan ajar dengan mengintegrasikan pendekatan saintifik dimaksudkan untuk menghasilkan bahan ajar dengan menerapkan beberapa model dengan pendekatan saintifik serta pemanfaatan teknologi (web) sebagai media demi terciptanya bahan ajar yang inovatif dan interaktif (Henni Fitriani, Manihar Situmorang, and Ayi Darmana, 2017, h. 49). Bahan ajar gamifikasi menampilkan gambargambar yang menarik untuk menunjang kemampuan penalaran, pemecahan masalah dan komunikasi matematis peserta didik.

Berdasarkan uraian yang telah dikemukakan, maka rumusan masalah dalam peneitian ini yaitu "Bagaimana pengembangan bahan ajar gamifikasi materi peluang layak dan menarik untuk digunakan siswa SMP?”. Adapun tujuan yang ingin dicapai dari peneliti adalah untuk mengetahui pengembangan bahan ajar gamifikasi materi peluang layak dan menarik untuk digunakan peserta didik SMP.

\section{METODE PENELITIAN}

Penelitian ini menggunakan metode penelitian ADDIE. Fungsi dari model ADDIE adalah menjadi pedoman dalam membangun perangkat dan infrastruktur program pembelajaran yang efektif, dinamis dan dan mendukung kinerja pembelajaran itu sendiri (Bilfaqih Yusuf, 2009, h. 10). Model ini terdiri dari lima tahapan, yaitu Analisis (Analysis), perencanaan (Design), pengembangan (Development), implementasi (Implementation) dan evaluasi (Evaluation). Deskipsi tahapan ADDIE yang dilakukan peneliti dalam pengembangan bahan ajar gamifikasi berbasis Contextual Teaching Learning (CTL) adalah sebagai berikut:

\section{Analisis (Analysis)}

Tahapan analisis (analysis) meliputi kegiatan sebagai berikut (Tegeh I Made, Jampel I Nyoman, and Ketut Pudjawan, 2014, h.42):

a. Analisis kompetensi yang ditujukan kepada peserta didik.

Analisis kompetensi yang ditujukan kepada peserta didik bertujuan untuk mengetahui kompetensi yang dimiliki peserta didik sehingga peneliti dapat mengetahui apa yang dibutuhkan oleh peserta didik dalam pengembangan bahan ajar berupa bahan ajar gamifikasi. 
b. Analisis karakteristik peserta didik tentang kapasitas belajar, pengetahuan, penampilan, sikap yang telah dimiliki peserta didik serta aspek lain yang terkait.

Tahap ini bertujuan untuk mengetahui seberapa paham peserta didik dengan materi peluang yang sudah diajarkan pendidik. Perbedaan karakter yang ada pada peserta didik merupakan hal yang wajar dan tentunya sangat perlu diperhatikan dalam pembelajaran. Bahan ajar yang digunakan dalam pembelajaran harus dikembangkan dengan memperhatikan karakter peserta didik sehingga sesuai dengan peserta didik. Karakteristik perserta didik yang perlu di perhatikan antara lain kemampuan akademik individu, fisik, motivasi belajar, latar belakang ekonomi dan sosial, pengalaman belajar sebelumnya, dsb. Analisis karakteristik tersebut, peneliti akan menyesuaikan isi bahan ajar gamifikasi sesuai dengan karakteristik peserta didik.

c. Analisis materi sesuai dengan tuntutan kompetensi.

Bahan ajar sebagai media pembelajaran sebaiknya sesuai dengan materi-materi pokok, sub-sub bagian dari materi pokok, anak sub bagian dan seterusnya.

\section{Tahap Perencangan (Design)}

Tahap perancangan (design) difokuskan pada tiga kegiatan, yaitu memilih materi sesuai dengan karakteristik peserta didik dan tuntunan kompetensi, strategi pembelajaran yang diterapkan dan bentuk serta metode assesmen dan evaluasi yang digunakan.

\section{Tahapan Pengembangan (Development)}

Pada tahapan ini peneliti mengkonkretkan hasil perencanaan pada tahapan design. Rancangan produk yang telah dikonsep kemudian dikembangkan produk sesuai dengan materi, kebutuhan peserta didik, gambar-gambar ilustrasi lain sebagainya.

\section{Implementasi (Implementation)}

Setelah bahan ajar dinyatakan valid dan layak, maka bahan ajar gamifikasi ini digandakan sebanyak jumlah yang dibutuhkan dan kemudian diimplementasikan dalam kegiatan pembelajaran di sekolah. Uji coba ini dilakukan dengan cara siswa menggunakan modul tersebut untuk mempelajari materi Peluang. Kemudian dilanjutkan dengan pengisian angket oleh peserta didik yang telah menggunakan bahan ajar gamifikasi tersebut. Hal ini bertujuan untuk mendapatkan beberapa respon yang meliputi kepraktisan dan keefektifan modul. Hasil tersebut sebagai bahan yang dijadikan acuan revisi sehingga modul menjadi lebih baik.

\section{Evaluasi (Evaluation)}


Berdasarkan tahapan implementasi, bahan ajar gamifikasi perlu dievaluasi. Evaluasi diperoleh dari hasil angket peserta didik dan pendidik, wawancara pendidik, dan catatan lapangan. Tahap evaluasi dilakukan revisi akhir terhadap produk yang dikembangkan berdasarkan masukan peserta didik yang diberikan selama tahap implementasi, karena mungkin masih terdapat kekurangan-kekurangan pada bahan ajar gamifikasi tersebut. Berdasarkan keseluruhan proses, maka bahan ajar gamifikasi yang dikembangkan diharapkan layak digunakan untuk pembelajaran matematika karena telah memenuhi aspek kualitas yang ditinjau dari segi kelayakan isi, bahasa, media dan kesesuaian dengan pendekatan kontekstual serta aspek kepraktisan.

Rumus menghitung skor penilaian total dapat dicari dengan menggunakan rumus sebagai berikut (Rully Anggraini And Rizki Wahyu Yunian Putra, 2016, h. 5):

$$
\bar{x}=\frac{\sum_{i=1}^{n} x_{i}}{n}
$$

dengan:

$$
x_{i}=\frac{\text { jumlah } \text { skor }}{\text { skor maks }} \times 4
$$

keterangan: $\quad \bar{x}=$ rata-rata akhir

$$
\begin{aligned}
x_{i}=\text { nilai uji operasional angket tiap siswa } & \\
& n=\text { banyaknya siswa yang mengisi angket }
\end{aligned}
$$

Langkah selanjutnya angket validasi ahli terkait kegrafikan, penyajian, kesesuaian isi, kebahasaan dan kesesuaian bahan ajar 4 pilihan jawaban sesuai konten pertanyaan. Masingmasing memilih jawaban memiliki skor berbeda yang mengartikan tingkat validasi bahan ajar gamifikasi materi peluang. Skor penilaian dari tiap pilihan jawaban dapat dilihat dalam Tabel 1 (Lucky Chandra Febriana, 2014, h.5).

Tabel 1. Skor Penilaian Validasi Ahli

\begin{tabular}{cc}
\hline Skor & Pilihan jawaban kelayakan \\
\hline 4 & Sangat baik \\
3 & Baik \\
2 & Kurang baik \\
1 & Tidak baik \\
\hline
\end{tabular}

Sumber Data: Lucky Chandra

Hasil dari skor penilaian dari masing-masing validator ahli media, ahli materi dan ahli bahasa tersebut kemudian dicari rata-ratanya dan dikonversikan ke pernyataan untuk menentukan kevalidan dan kelayakan bahan ajar gamifikasi. Pengonversian skor menjadi pertanyaan penilaian ini dapat dilihat dalam Tabel 2 (Rubhan Masykur et al, 2017, h. 181). 


\begin{tabular}{ccc}
\multicolumn{3}{c}{ Tabel 2. Kriteria Validasi Ahli } \\
\hline skor kualitas & kiteria Kelayakan & Keterangan \\
\hline $3,26<\bar{x} \leq 4,00$ & valid/sangat layak digunakan & tidak refisi \\
$2,51<\bar{x} \leq 3,26$ & cukup valid/layak digunakan & Revisi sebagian \\
$1,76<\bar{x} \leq 2,51$ & kurang valid /layak digunakan & Refisi sebagian \& pengkajian ulang \\
$1,00<\bar{x} \leq 1,76$ & tidak valid/layak digunakan & materi \\
Sumber Data : Rubhan Maskur & Revisi total
\end{tabular}

Sedangkan angket respon siswa terhadap pengunaan produk memiliki 4 pilihan jawaban sesuai konten pertanyaan. Masing-masing jawaban memiliki skor berbeda yang mengartikan tingkat kesesuaian produk bagi pengguna. Skor penilaian dari tiap pilihan jawaban dapat dilihat dalam Tabel 3 (Rinaldi Indra Santoso, Ciptono, and Triatmanto, 2016, h. 3).

\begin{tabular}{cc}
\multicolumn{2}{c}{ Tabel 3. Skor Penelitian Terhadap Pilihan Jawaban } \\
\hline Skor & Pilihan jawaban kelayakan \\
\hline 4 & Sangat baik \\
3 & Baik \\
2 & Kurang baik \\
1 & Tidak baik \\
\hline Sumber Data : Rinaldi Indra Santoso
\end{tabular}

Hasil dari skor penilaian dari masing-masing siswa tersebut kemudian dicari rata-rata dan dikonversikan kepernyataan untuk menentukan kemenarikan dan kemudahan bahan ajar gamifikasi materi peluang. penkonversian skor menjadi penyelesaian penilaian ini dapat dilihat dalam Tabel 4 (Ana Kurnia Sari, Chandra Ertikanto, and Wayan Suana, 2015, h. 5).

Tabel 4. Kriteria Untuk Uji Kemenarikan dan Kemudahan

\begin{tabular}{cc}
\hline Skor kualitas & $\begin{array}{c}\text { Pertanyaan kualitas aspek kemenarikan dan } \\
\text { kemudahan }\end{array}$ \\
\hline $3,26<\bar{x} \leq 4,00$ & Sangat menrik / sangat mudah digunakan \\
$2,51<\bar{x} \leq 3,26$ & Menarik / mudah digunakan \\
$1,76<\bar{x} \leq 2,51$ & Kurang menarik / sulit digunakan \\
$1,00<\bar{x} \leq 1,76$ & Sangat Kurang menarik / sangat sulit digunakan \\
\hline Diadopsi dari Ana Kurnia Sari &
\end{tabular}

\section{HASIL DAN PEMBAHASAN}

\section{Tahap Analisis (Analysis)}

Tahap analisis dilakukan penelitian pendahuluan yaitu observasi dan wawancara terhadap guru dan siswa. Penelitian pendahuluan ini meliputi observasi kegiatan pada saat proses belajar mengajar, penggunaan media pembelajaran, wawancara terhadap guru pengampu mata pelajaran matematika, serta penyebaran soal untuk mengetahui pengetahuan awal siswa terhadap mata pelajaran matematika khususnya pada materi peluang. Tujuan pendahuluan ini yaitu memperoleh data aspek analisis kebutuhan yang diperoleh sebagai berikut:

1) Analisis kurikulum 
Kurikulum yang diterapkan di SMPN 3 Tanjung Raja Lampung Utara dan Mts Darul A'mal Metro menggunakan kurikulum 2013. Kurikulum tersebut digunakan khususnya untuk kelas VII pada materi peluang. Kopetensi tersebut terangkung dalam silabus mata pelajaran matematika materi peluang SMP/Mts kelas VIII.

2) Analisis media pembelajaran

Analisa media pembelajaran yang digunakan bertujuan untuk mengetahui media pembelajaran seperti apa yang diterapkan sebelumnya dimata pelajaran matematika. Data yang diperoleh dalam analisis media pembelajaran yaitu:

a) Pada saat pembelajaran matematika di SMPN 3 Tanjung Raja Lampung Utara dan Mts Darul A'mal metro guru masih menggunakan buku pelajaran yang tersedia sebagai sumber pembelajaran.

b) Guru tidak menggunaakn media secara interaktif sehingga menjadikan peserta didik cenderung pasif dalam mengikuti pembelajaran di kelas.

c) Peserta didik sedikit kesulitan untuk mengulang pembelajaran karena buku cetak yang digunakan memiliki tampilan yang kurang menarik dan membosankan sehingga pesta didik malas mempelajari materi materi yang belum dipahami dengan jelas.

Berdasarkan data pengamatan media pembelajaran yang digunkan guru pengampu tersebut maka diperoleh bahwa media yang digunakan guru dalam menyampaikan materi kurang optimal karena hanya menggunakan buku pelajaran yang kurang menarik dan tidak menggunakan media pembelajaran lain.

\section{Tahapan Perancangan (Design)}

Setelah dilakukan analisis kebutuhan selanjutnya adalah tahap perancangan pengembangan media. Bahan ajar gamifikasi yang dapat membantu guru dan peserta didik dalam proses pembelajaran adalah spesifikasi media yang dikembangkan. Berikut ini adalah perencanaan pengembangan bahan ajar gamifikasi sebagai media pembelajaran matematika yang dikembangkan:

a. Membuat cover yang menarik dengan menggunakan photoshop CS3.

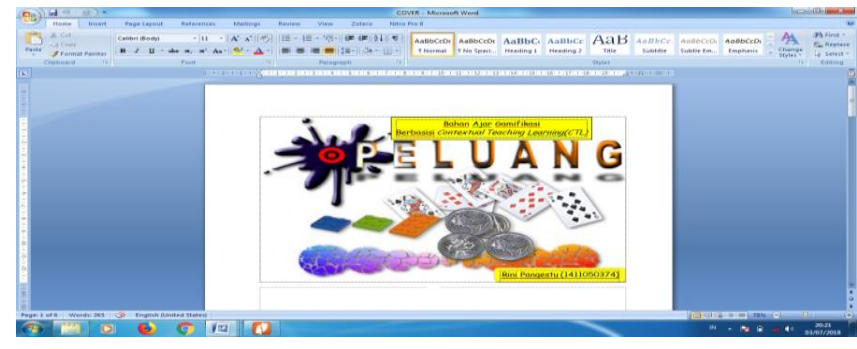

Gambar 1. Desain cover dengan photoshop CS3

Pengembangan Bahan Ajar Gamifikasi Berbasis Contextual Teaching Learning (CTL) 
b. Membuat konsep materi peluang di microsoft word dan sesuai dengan kompetensi inti dan kompetensi dasar dalam silabus.

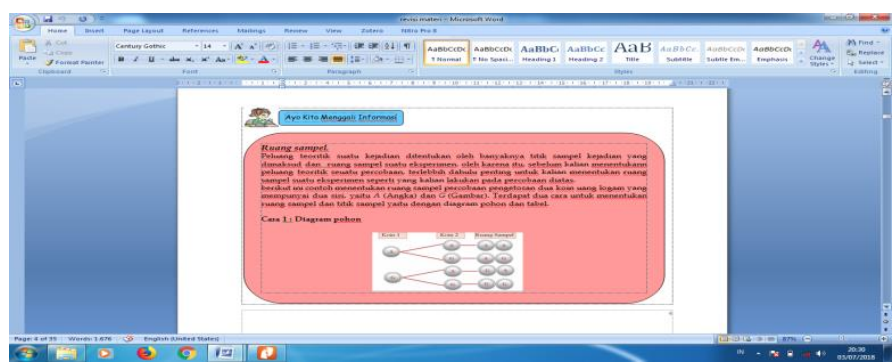

Gambar 2. konsep materi peluang berbentuk microsoft word

c. Mengaitkan materi peluang dengan bahan ajar gamifikasi berbasis Contextual Teaching Learning $(C T L)$.

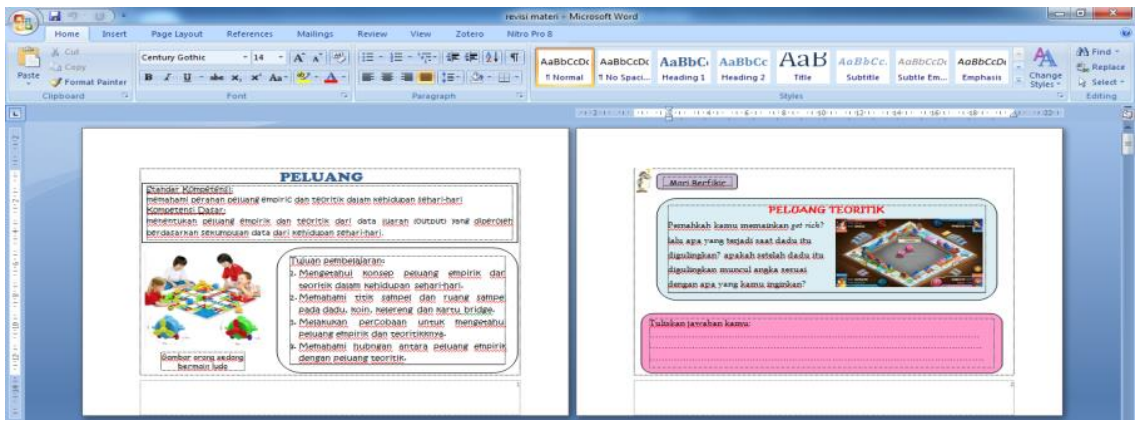

Gambar 3. Materi Peluang Berbentuk Contextual Teaching Learning(CTL)

d. Membuat contoh soal peluang dengan gamifikasi.

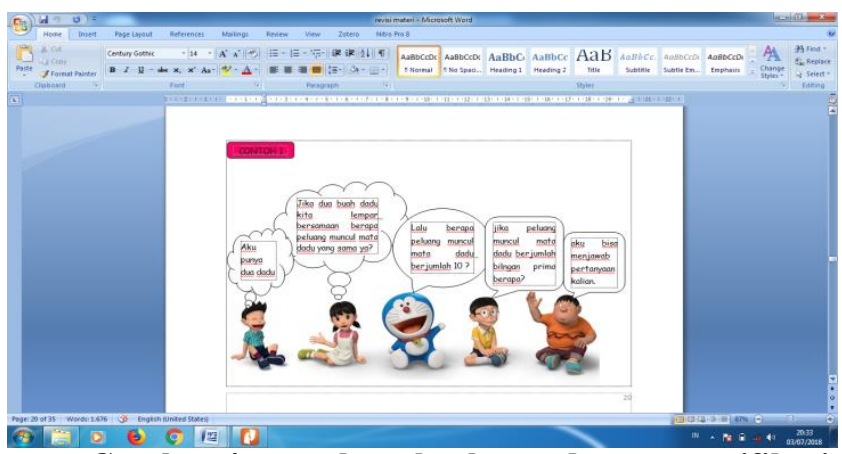

Gambar 4. contoh soal peluang dengan gamifikasi

e. Membuat game dalam bahan ajar.

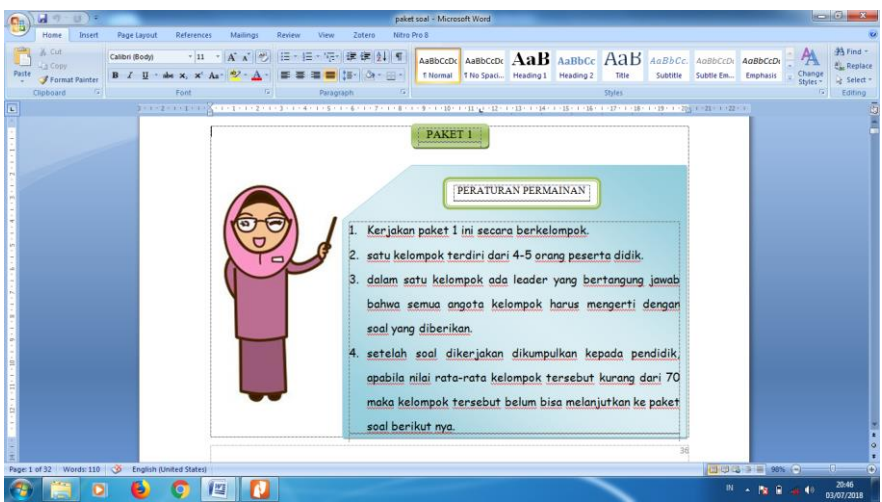

Gambar 5. Peraturan Game Dalam Bahan Ajar

Prima, Vol. 3, No. 1, Januari 2019, 45-56. 


\section{Tahap Pengembangan (Development)}

Pada tahapan ini dilakukan validasi ahli materi, ahli media dan ahli bahsa untuk melihat kelayakan produk serta uji coba lapangan untuk melihat kemenarikan respon peserta didik. Hasil validasi produk secara keseluruhan disajikan dalam Tabel 5.

Tabel 5. Hasil Validasi ahli materi

\begin{tabular}{|c|c|c|c|c|c|}
\hline \\
\hline \multirow{2}{*}{ No } & \multirow{2}{*}{ Aspek } & \multirow{2}{*}{ Analisi } & \multicolumn{3}{|c|}{ Validator } \\
\hline & & & 1 & 2 & 3 \\
\hline \multirow{5}{*}{1} & \multirow{5}{*}{ Kelayakan Isi } & $\sum$ Skor & 44 & 42 & 41 \\
\hline & & Nilai Max & 48 & 48 & 48 \\
\hline & & $\mathrm{xi}$ & 3,7 & 3,5 & 3,4 \\
\hline & & $X$ & \multicolumn{2}{|l|}{3,5} & \\
\hline & & kritera & \multicolumn{2}{|c|}{ Sangat layak } & \\
\hline \multirow{5}{*}{2} & \multirow{5}{*}{$\begin{array}{l}\text { Kelayakan } \\
\text { Penyajian }\end{array}$} & $\sum$ Skor & 32 & 32 & 30 \\
\hline & & Nilai Max & 36 & 36 & 36 \\
\hline & & xi & 3,6 & 3,6 & 3,3 \\
\hline & & $X$ & 3,5 & & \\
\hline & & kritera & Sang & it layak & \\
\hline \multirow{5}{*}{3} & \multirow{5}{*}{$\begin{array}{l}\text { Penilaian } \\
\text { Kontekstual }\end{array}$} & $\sum$ Skor & 32 & 32 & 32 \\
\hline & & Nilai Max & 36 & 36 & 36 \\
\hline & & xi & 3,6 & 3,6 & 3,5 \\
\hline & & $\mathrm{X}$ & 3,5 & & \\
\hline & & kritera & San & at layak & \\
\hline \multicolumn{2}{|c|}{ Rata-rata total } & & \multicolumn{2}{|l|}{3,5} & \\
\hline \multicolumn{2}{|c|}{ Kriteria } & & \multicolumn{2}{|c|}{ Sangat layak } & \\
\hline
\end{tabular}

Adapun hasil dari validasi ahli media ditujukan Tabel 6:

Tabel 6. Hasil Validasi ahli Media

\begin{tabular}{lllll}
\hline \multirow{2}{*}{ Aspek } & Analisis & Validator & \\
& & 1 & 2 & 3 \\
\hline \multirow{2}{*}{$\begin{array}{l}\text { kelayakan } \\
\text { kegrafikan }\end{array}$} & Nilai Max & 108 & 95 & 81 \\
& $\mathrm{X}$ & 3,5 & 3,5 & 108 \\
& Kritera & 3,3 & 3 \\
Rata-rata total & & Sangat layak & \\
Kriteria & & 3,3 & \\
\hline
\end{tabular}

Hasil validasi ahli bahasa ditujukan Tabel 7:

\section{Pengembangan Bahan Ajar Gamifikasi Berbasis Contextual Teaching Learning (CTL)


Tabel 7. Hasil Validasi ahli Bahasa

\begin{tabular}{llrrrr}
\hline \multirow{2}{*}{ Aspek } & Analisi & \multicolumn{4}{l}{ Validator } \\
& & 1 & & 2 & 3 \\
\hline & S Skor & & 31 & 31 & 27 \\
kelayakan & Nilai Max & & 36 & 36 & 36 \\
kebahasaan & Xi & & 3,4 & 3,4 & 3 \\
& X & 3,3 & & & \\
& Kritera & \multicolumn{3}{l}{ Sangat layak }
\end{tabular}

Kemudian jika diihat dari uji kelompok kecil yang dikakukan di Mts Darul A'mal Metro diperoleh hasil seperti Tabel 8.

Tabel 8. Hasil Uji Kelompok Kecil

\begin{tabular}{|c|c|c|c|c|c|}
\hline No & Responden & analisis & kemenarikan & materi & Bahasa \\
\hline \multirow{4}{*}{1} & \multirow{4}{*}{$\begin{array}{l}\text { siswa-siswi Mts } \\
\text { Darul A'mal } \\
\text { Metro }\end{array}$} & $\sum$ Skor & 589 & 590 & 307 \\
\hline & & $\mathrm{xi}$ & 3,3 & \multirow[t]{3}{*}{3,3} & \multirow[t]{3}{*}{3,4} \\
\hline & & $X$ & 3,3 & & \\
\hline & & Kritera & sangat menarik & & \\
\hline
\end{tabular}

Selanjutnya, jika dilihat dari ujicoba kelompok besar yang dilakukan di SMPN 3 Tanjung Raja Lampung Utara diperoleh hasil seperti Tabel 9:

Tabel 9. Hasil Uji Kelompok Besar

\begin{tabular}{llllll}
\hline no & responden & analisis & kemenarikan & Materi & bahasa \\
\hline \multirow{4}{*}{1} & siswa-siswi SMPN 3 & E Skor & 643 & 664 & 340 \\
& Tanjug Raja & xi & 3,2 & 3,4 & 3,4 \\
& Lampung utara & X & 3,3 & & \\
& & kritera & sangat menarik & &
\end{tabular}

Penilaian validator ahli materi, ahli media dan ahli bahasa terhadap prodk bahan ajar gamifikasi diperoleh hasil yang sangat baik. Sementara itu, hasil validasi ahli yang dilakukan 3 validator ahli materi memperoleh nilai rata-rata 3,5 dengan kriteria "sangat layak". Validasi ahli media memperoleh nilai rata-rata 3,3 dengan kriteria "sangat layak". Sedangkan validasi ahli bahasa memperoleh nilai rata-rata 3,3 dengan kriteria "sangat layak". Hasil validasi ahli dilakukan oleh 9 validator. Secara keseluruhan validator diperoleh nilai rata-rata 3.4 kriteria "sangat layak". Hal ini menunjukan bahwa bahan ajar gamifikasi yang dikembangkan sudah sesuai dengan keyentukan yang berlaku.

Selain hasil dari penilaian para validasi ahli, diperoleh pula hasil dari ujicoba kelompok kecil dan ujicoba kelompok besar. Berdasarkan uji coba poduk dengan kelompok kecil pada Tabel 8, dapat diketahui bahwa pada aspek kemenarikan dan materi memperoleh nilai rata-rata 3,3 dengan kriteria "sangat menarik" serta aspek bahasa memperoleh nilai rata-rata 3,4 dengan kriteria "sangat menarik". Sedangkan berdasarkan hasil uji coba kelompok besar pada Tabel 9, 
dapat diketahui bahwa pada aspek kemenarikan memperoleh nilai rata-rata 3,2 dengan kriteria "sangat menarik". Aspek materi dan bahasa memperoleh nilai rata-rata 3,4 dengan keiteria "sangat menarik".

Dengan demikian, dari hasil validasi ahli dan uji coba yang telak dilakukan dapat disimpilkan bahwa bahan ajar gamifikasi berbasis Contextual Teaching Learning (CTL) dinyatakan sangat layak dan sangat menarik untuk digunakan pada jenjang SMP/Mts sebagai bahan ajar untukpendidik maupun peserta didik.

\section{SIMPULAN DAN SARAN}

Berdasarkan hasil pengembangan dapat disimpulkan bahwa:

1. pengembangan bahan ajar gamifikasi berbasis Contextual Teaching Learning (CTL) pada materi peluang layak dan menarik bagi siswa. pengebangan bahan ajar gamifikasi telah divalidasi oleh ahli materi, ahli bahasa dan ahli media dengan memperoleh kriteria sangat layak.

2. Ujicoba kemenarikan bahan ajar gamifikasi yang diujicobakan pada kelompok kecil dan kelompok besar, pada uji kemenarikan memperoleh kriteria sangat menarik.

Hasil penelitian, analisis pembahasan dan kesimpulan dapat dikemukakakn beberapa saran sebagai berikut:

1. Pembelajaran menggunakan bahan ajar gamifikasi dapat dikembangkan oleh pendidik secara berkelanjutan untuk materi yang berbeda.

2. Mengujicobakan kegiatan pembelajatan menggunakan bahan ajar gamifikasi pada subjek peneltian yang berbeda.

3. Pembuatan bahan ajar gamifikasi dapat ini dapat beberapa kendala atau kesulitan yang mungkin biasa menjadi perbaikan bagi peneliti berikutnya untuk mengembangkan bahan ajar gamifikasi dengan materi yang lain atau dengan berbantuan media lain supaya lebih mudah untuk dipahami oleh peserta didik.

\section{DAFTAR PUSTAKA}

Bilfaqih, Y. (2009). Esensi Penyusunan Materi Pembelajaran. Yogyakarta: CV Budi Utama. Chandra, L. (2014). Pengembangan Lembar Kerja Siswa (LKS) Fisika Materi Tekanan Mencakup Ranah Kognitif, Asfektif Dan Psikmotor Sesuai Kurikulum 2013 Untuk Siawa SMP/SMA. Jurnal Pendidikan . 
Durohman, Muchamad Subali Noto, dan Wahyu Hartono. (2018). Pengembangan Perangkat Project Based Learning (Pjbl) Pada Materi Statistika Sma. Prima Jurnal. Vol. 2, No. 1.

Fitiani, H., Sitomang, M., \& Darmana, A. (2017). Pengembangan Bahan Ajar Inovatif dan Interaktif Melalui Pendekatan Saintifik Pada Pengajaran Larutan dan Kaloid. Jurnal Edukasi Kimia .

Idi, A. (2014). pengembangan kurikulum teori dan praktik. jakarta: pt rajagrafindo persada.

Maskur, R., Novanto, \& syazali, M. (2017). Pengembangan Media Pembelajaran Matematika Dengan Macromedia Flas. Jurnal Pendidikan Matematika, ISSN 2086-5872, Vol. 8, No. 2.

Putra, R. W., \& Rully, A. (2016). Pengembangan Bahan Ajar Trigonometri Berbantuan Sofwere iMindMap Pada Siswa SMA. Jurnal Pendidikan Matematika, ISSN 20865872, Vol. 7, No. 1 .

Umar, G. P., \& Rohayati, S. (2015). Pengembangan Bahan Ajar Modul ebahai Pendukung Impementasi Kurikulum 2013 Pada Mata Pelajaran Akutansi SMKN 1 Surabaya. Jurnal Universitas Negeri Surabaya .

Tegeh, I. M., Jampel, N., \& Pudjawan, K. (2014). Model Penelitian. Yogyakarta: Graha Ilmau.

Santoso, R. I., \& Trianmojo, C. (2016). Pemngembangan Modul Berbasis WEB Materi Prozoa Sebagai Alternatif Bahan Ajar Kelas X SMA Negeri1 Sewon. Jurnal Pendidikan Biologi, Universitas Yogyakarta 